\title{
EUROPEAN INFLUENCE ON ETHIOPIAN ANTITRUST REGIME:
}

\author{
A Comparative and Functional Analysis of Some Problems
}

Hailegabriel G. Feyissa*

\section{Introduction}

Despite a noticeable European influence on the Ethiopian competition legal regime, some aspects of Ethiopia's 2003 Trade Practice Proclamation are still inadequate to appropriately deal with certain competition problems. The limitations of the rules need to be put right since achievement of the very goals of competition law requires a well designed set of competition rules and effective implementation schemes.

This article attempts to make a brief comparative and functional analysis of some of the major inadequacies of the Trade Practices Proclamation. A brief appreciation of the background to the 2003 Ethiopian Trade Practice Proclamation and a subsequent perusal at the European marks of the same will serve as stepping stones to comparative and functional analysis of some problems related to the Ethiopian antitrust regime. Finally, I argue in favour of a functionally sound approach to solve some problematic aspects of the existing Ethiopian competition legislation.

\section{Background: Free Market and Competition Regulation in Ethiopia}

Regulation of competition is a fairly recent phenomenon in Ethiopia. Before 1991, the economic policy in Ethiopia was not based on the ideals of free market aside from the introduction of a mixed economic policy around 1990 . The military (socialist) regime - that seized power after the 1974 revolution took measures that reduced the role of the private sector and the free market that had started to flourish during the imperial regime of Haile Selassie. ${ }^{1}$ Consequently, key motives for the regulation of competition, e.g. (a failure in) a free market, were absent from the outset.

* LL.B, LL.M (University of Groningen), Lecturer in Law, Bahir Dar University

${ }^{1}$ Before 1974, Emperor Haile Selassie's (1930-1974) Ethiopia opted for market oriented mixed economy which saw a considerable involvement in the economy by the private sector; see, e.g., Kibre M., Policy-induced Barriers to Competition in Ethiopia, Jaipur, CUTS International, 2007, at 4 (hereinafter Kibre). 
Works to bring the market back into play have been done since the last decade of the previous millennium, after the downfall of the socialist regime. As part of the move towards liberalised and free market economy, different restructuring works has been put in place. $^{2}$ The different schemes of liberalisation have enhanced the role of the private sector in the Ethiopian economy. Would this, however, guarantee smooth competition in the actual market? The answer would be in the negative. Neither privatization of nationalised industries nor opening up of previously closed markets would necessarily guarantee smooth competition in the actual market as there are structural barriers inherited from the previous system which created monopolies in various sectors. Moreover, the absence of competition culture may tempt some businessmen, dominant or non-dominant, to engage in restrictive business practices. Such problems could only be dealt with appropriately if competition is regulated.

Ethiopia enacted its first ever competition law only in 2003 - more than a decade after it started a move away from socialism. One could see the 2003 Trade Practice Proclamation as part of the worldwide surge in competition legislation happening after the demise of socialism in Eastern Europe. The growing consensus that antitrust law is not a luxury, but a necessity, to developing free market states - that are not of course invulnerable to anticompetitive practices - has been one of the main driving forces behind the growing interest among states like Ethiopia in antitrust regulation. The universal rise in competition endorsement has also been motivated by factors external to the concerned states. Ethiopia does not seem to be an exception to this. $^{3}$ As would be seen in the forthcoming sections, Ethiopia's antitrust regulation has benefited from the already well developed competition statutory and case laws of the traditional free market economies - most importantly that of Europe.

2 These, for example, include privatisation of previously nationalised enterprises and enactment of new legislation allowing the participation of the private sector in areas that in the past were closed to them; Kibre rightly notes that these restructuring processes could be understood as being part and parcel of a broad competition policy; Kibre, p.4 et seq.

${ }^{3}$ In part, Ethiopia's competition law seems to be the result of Ethiopia's engagement in regional common markets (see below for more on this). The conditioning of funds [from international funding agencies (IMF and World Bank)] on a range of liberalisation issues which include the adoption of different competition policies, including law, is the other likely reason for the adoption of the competition law. 


\section{Antitrust Rules in the Trade Practice Proclamation: Its European Marks}

Ethiopian antitrust regulatory rules are embodied in the Trade Practice Proclamation (TPP) enacted in 2003. In Part Two of the Proclamation, particularly Articles 6-11, spell out two of the three conventional competition rules. While Art.6 deals with anti-competitive practices (cartels), Art.11 prohibits abuse of dominance. The first of the two provisions reads "No person may directly or indirectly enter into any written or oral agreement that restricts limits, impedes or in any other way harms free competition, in the process of production, supply, distribution or marketing of goods and services." 4

Apart from this general rule, the same article provides some exemplary anti-competitive practices which include: (a) agreements of jointly fixing prices; (b) agreements for collusive tendering as to determine market price; (c) agreements as to market or consumer segmentation; (d) agreements as to allocation by quota of production and sales; (e) concerted refusal to deal, sell and render services.

Article 11, on the other hand, contains the Ethiopian rule on abuse of dominance. Accordingly, "no person may carry on trade which gives opportunity to control a relevant market for goods or services; or limit access to a relevant market or otherwise unduly restrain competition, having or being likely to have adverse effects on market development."5 Like Article 6(1), the general rule in Article 11(1) is followed by some illustrative abuses [by a dominant undertaking]. Inter alia, these include (a) the direct or indirect unfair imposition of excessively high or low selling price or service fee or withholding supply or any pre-emptive behaviour to impede entry into market; (b) the selling of similar goods or services to consumers on unequal terms or payments; (c) the application to dealers in transaction of unequal terms in respect of similar goods thereby placing some at competitive disadvantage; (d) to impose a condition of combined sales on a buyer when the goods or services so combined are not required by the buyer; (f) refusing sales of goods or services to customers without good cause; and (g) selling at a price that does not cover production cost to eliminate fair competition. ${ }^{6}$

\footnotetext{
${ }^{4}$ Art.6 (1), TPP.

${ }^{5}$ Ibid, Art.11 (1).

6 The appropriateness of the inclusion of some of these specific abusive practices is questioned by some; see, e.g., a report by USAID, Ethiopia Commercial Law \& Institutional Reform and Trade Diagnostic, USAID, 2007 at 60[hereinafter USAID
} 
The European marks on the Ethiopian rules on anti-competitive practices or restrictive business practices (RBP) are very visible. A cursory look at Art.6, TPP and its European equivalent - Art.81, the 1957 Rome Treaty establishing the European Community (EC Treaty) - reveals that the latter has been the primary material source to the former. The text of Art.81 (1) of the EC Treaty reads:

The following shall be prohibited as incompatible with the common market: all agreements between undertakings, decisions by associations of undertakings and concerted practices which may affect trade between Member States and which have as their object or effect the prevention, restriction or distortion of competition within the common market, and in particular those which:

a) directly or indirectly fix purchase or selling prices or any other trading conditions;

b) limit or control production, markets, technical development, or investment;

c) share markets or sources of supply;

d) apply dissimilar conditions to equivalent transactions with other trading parties, thereby placing them at a competitive disadvantage;

e) make the conclusion of contracts subject to acceptance by the other parties of supplementary obligations which, by their nature or according to commercial usage, have no connection with the subject of such contracts.

This provision is the basis for numerous domestic antitrust rules on RBP, both within and outside Europe. Apparently, the Ethiopian antitrust rules on RBP are equally inspired by this European material source. Despite the absence of complete verbal similarity between the corresponding provisions of the TPP and the EC Treaty, Art.6 (1) of the former is noticeably influenced by the Art.81(1) of the latter. Firstly, same as the latter, the former declares that any form of agreement that prevents, restricts, or impedes competition is prohibited. Secondly and most importantly, Art.6 (2), TPP takes on the illustrative anti-competitive practices enumerated under Art.81 (1), EC Treaty. For instance, one may look at the striking similarity between (1) the order and (2) type of illustrative RBPs listed under Art.6 (2), TPP and Art.81 (1), EC Treaty. ${ }^{7}$

Report]; Harqa H., Competition Policies and Laws: Major Concepts and an Overview of Ethiopian Trade Practice Law, 2 Mizan Law Review 33 (2008), at 48[hereinafter Harqa].

${ }^{7}$ Both under Art.6 (2), TPP and Art.81 (1), EC Treaty, joint price fixing is the first in the list of illustrative RBPs. Moreover, note that Art.6 (2), TPP adopts [directly or indirectly] almost every single illustrative RBPs mentioned in Art.81 (1), EC Treaty. 
Incidentally, it is worth noting that Ethiopia has apparently enacted its rules on RBP in accordance with Art. $55^{8}$ of the Common Market for Eastern and Southern Africa (COMESA) Treaty, which itself is comparable, if not identical, with its European counterpart, i.e., Art.81 of the EC Treaty. Membership in the Common Market entails, inter alia, the enactment of domestic antitrust legislation or the application of the regional Treaty rules to domestic competition matters. ${ }^{9}$ In other words, Ethiopian rules on anticompetitive practices are, in part, the result of Ethiopia's commitment to the regional free trade arrangement, COMESA.

The prohibitions embodied in Art.11 of TPP are also comparable with those under Art.82 of the EC Treaty. Art.82 of the EC Treaty, embodying the European law on abuse of dominance stipulates:

Any abuse by one or more undertakings of a dominant position within the common market or in a substantial part of it shall be prohibited as incompatible with the common market in so far as it may affect trade between Member States. Such abuse may, in particular, consist in:

a) directly or indirectly imposing unfair purchase or selling prices or other unfair trading conditions;

b) limiting production, markets or technical development to the prejudice of consumers;

c) applying dissimilar conditions to equivalent transactions with other trading parties, thereby placing them at a competitive disadvantage;

d) making the conclusion of contracts subject to acceptance by the other parties of supplementary obligations which, by their nature or according to commercial usage, have no connection with the subject of such contracts.

As it is the case with the Ethiopian rules on cartels, the rules on abuse of dominance bear European origin. The very preference of the term abuse of

\footnotetext{
8 The text of this article, inter alia, reads: “... the Member States agree to prohibit any agreement between undertakings or concerted practice which has its object or effect the prevention, restriction or distortion of competition within the Common Market..." Note the verbal similarity between the texts of this article and its European counterpart.

${ }^{9}$ Ethiopia and other member states have been assisted by COMESA in developing their respective domestic competition legislations. Apparently, states who fail to adopt one or another piece of law are obliged to apply the regional competition rule enshrined under Art.55, COMESA Treaty; see Stewart T., Clarke J. \& Joekes S., Competition Law in Action: Experience from Developing Countries, International Development Research Centre, Ottawa, 2007, at 45[hereinafter, Stewart, Clarke \& Joekes].
} 
dominance, instead of anti-monopolisation, itself confirms the European root of the rule as the term was first coined and used in Europe. ${ }^{10}$ Furthermore, the marked similarity [in form and content] between Art.11, TPP and Art.82, EC Treaty tells the rest.

Institutions of antitrust enforcement might as well manifest instances of European influence on the Ethiopian antitrust regime. An administrative body - Trade Practice Investigation Commission - has been set up to enforce the regulation. Answerable to the Ministry of Trade and Industry, the Commission is empowered to (1) investigate complaints submitted to it by any aggrieved party, (2) to take administrative measures or/and give penalty decisions. ${ }^{11}$ Thus, Ethiopian competition law is set to be enforced within the context of administrative law. At this point as well, the Ethiopian system is generally comparable with the European - where, unlike in the US, antitrust cases are initially and mainly enforced administratively.

As could be evident from the discussion so far, the Ethiopian antitrust regulation is modelled after that of advanced western free market economies, i.e., mainly that of Europe. Apart from the formal and substantive similarity between Ethiopian and European antitrust rules, Ethiopia's preference of administrative, than judicial, enforcement antitrust is seemingly inspired by European experience.

Incidentally, one may question whether there would be any sound reason for a developing country like Ethiopia to opt for antitrust law that "mirrors" that of developed free market economies of Europe? Put differently, would Ethiopia's adoption of an antitrust regime based primarily on developed free market economies be level-headed in face of the triumphant argument that "there is no unique universally applicable competition law and policy"? ${ }^{12}$

First, core principles of competition law hold good for all states and could be part of any antitrust law. ${ }^{13}$ The traditional motive underlying antitrust regulation - the fear of inefficiency resulting from monopoly power - is hardly absent in Ethiopia. Least developed states like Ethiopia cannot afford

${ }^{10}$ Europeans use the term abuse of dominance to identify what in USA and similar jurisdictions is generally known as "anti -monopolisation” rules.

${ }^{11}$ Art.12 et seq.,TPP

12 This argument is underlined on the fact that there are huge socio-economic, political and cultural differences between developed and developing nations.

${ }^{13}$ See, e.g., Adhikari R. \& Knight-John M., What Type of Competition Policy and Law Should a Developing Country Have?, South Asia Economic Journal, 5(2004), at 2 (hereinafter Adhikari \& Knight-John); Dimgba N., Introduction to Competition Law: a sine qua non to a Liberalised Economy, 2006 , at 30(available at: www.globalcompetitionforum.com) [hereinafter Dimgba] 
inefficiency. Second, the science/art of antitrust regulation in traditional free market states - where the regulation has been tested by practice for decades readily supplements the understanding, in the receiving state, of meanings of the core principles. ${ }^{14}$ Moreover, the ever changing character of antitrust concerns in traditional free market states would give insights into improved competition policy objectives in emerging free market economies. Therefore, Ethiopia or other emerging free market countries, may pick up elements out of the major pre-existing antitrust regulatory systems, which best suits their context. ${ }^{15}$

\section{What to Expect from the Enforcement of the Antitrust Rules}

Regulating markets through state intervention has been necessitated for markets do not always work "perfect". Put in other words, market failure provides the very typical rationale for government regulation of the market. ${ }^{16}$ Governments of various free market economies intervene mainly through competition policies/regulations. ${ }^{17}$ What do we mean by "market failure"? Why does it matter? What do we specifically want to achieve by intervening in a failed market?

At least within the context of antitrust regulation, market is said to have failed when competition is eliminated from a certain market. The elimination of competition from a certain free market matters because it takes away, according to a highly persuasive economic theory, the greatest benefits which otherwise would be there in the presence of competition. ${ }^{18}$ What is disadvantageous to the society is not necessarily the absence, in a certain market, of competition. It is rather the eventual economic loss - what is usually known as deadweight loss - that provides the economic raison d'être behind antitrust regulation. The major concerns of antitrust regulation are summarized by Viscusi et al:

“...because of the control over the price exerted by a monopoly [market power that may be created through the elimination of competition] there are economic efficiency losses to society. Product quality and diversity may also be affected.

\footnotetext{
${ }^{14}$ Dimgba, at 30.

${ }^{15}$ For instance, Joan-Ramon Borrell recommends either American or European antitrust regime or a blend of the two depending on the strength of law enforcement institutions in a specific country. For details see generally Borrel J., Choosing among American, European, or no Antitrust at all, 2005(available at www.ssrn.com), [hereinafter Borrel]

${ }^{16}$ Bowels R., Law and the Economy, Martine Robertson \& Comp., Oxford, 1985, at 165.

${ }^{17}$ Harqa, at 35.

${ }^{18}$ Johns A. \& Sufrin B., EC Competition Law: Text, Cases and Materials, 3rd Edition, OUP, London, 2008, at 1. [hereinafter Johns \& Sufrin]
} 
Society could potentially be better off if limitations were imposed on the operation of a monopoly or a similar kind of concentrated industry.”19

Law and economics scholars agree that one, if not the sole, aim of regulating competition is to maintain the competitiveness of a certain free market for it maximises efficiency and, in return, promotes public [consumer] welfare. Though antitrust regulations in different jurisdictions have not always been enacted with the sole aim of efficiency, efficiency [along with consumer welfare] still remains the primary goal we specifically want to achieve by intervening in a failed market.

TPP has two expressly stated objectives: (1) to bring a fair competitive process through the prevention and elimination of anti-competitive practices, and (2) to safeguard the interests of consumers through the prevention of any restraints on the efficient supply and distribution of goods and services. Accordingly, maintaining the competitive process (or the presumably efficient supply and distribution mechanism) in the actual market through the elimination of RBPs for the benefit of the society at large and the consumer in particular is the economic rationale behind antitrust regulation in Ethiopia. These economically sound objectives - the most widely recognised objectives of competition law elsewhere - are not supplemented ${ }^{20}$ by other stated objectives although some specific provisions, as would be seen below, make us doubt the exclusiveness of the two expressly stated economic objectives. In the immediately following section, the adequacy of some specific regulatory rules of the TPP in achieving these economic objectives is appraised.

\section{A Comparative and Functional Inquiry into Some Aspects of the Ethiopian Law}

\section{A. the Limited Scope of Application: Robbing the Regulation its Main Targets?}

In most antitrust regimes, the scope of application of the law is broad enough to include as many economic activities as possible. But, some carefully designed limitations on the scope of application are recognised. In Europe, for

\footnotetext{
${ }^{19}$ Viscusi W., Vernon J. \& Harrington J, Economics of Regulation and Antitrust, $2^{\text {nd }}$ Edition, MIT Press, Cambridge, 1998, at 5.

${ }^{20}$ Other specific objectives of competition law are recognised in different countries. The 1998 Competition Act of South Africa, for instance, has, inter alia, the objective of encouraging small and medium sized enterprises so as "to promote a greater spread of ownership, in particular to increase the ownership stakes of historically disadvantaged persons"; Stewart, Clarke \& Joekes, at 21 et seq.; also, some country-specific factors determine objectives of competition law and policy (see, e.g., Adhikari \& Knight-John, at 3-5).
} 
instance, certain specific sectors are made outside the scope of application of certain competition rules. ${ }^{21}$ Inter alia, this is justified in terms of services of general economic interest which, if competition rules are applied, may not be provided adequately. ${ }^{22}$ Other public interest considerations have also been used to either limit or broaden the scope of application of competition law. ${ }^{23}$

In Ethiopia, as well, antitrust regulation seems to exclude certain firms and economic sectors from its scope of application. As a rule, the proclamation applies to all persons involved in any commercial activity. Exceptionally, the inapplicability of the law may, on a case by case basis, be considered if (1) commercial activities that are, according to investment proclamation, exclusively reserved for the Government; (2) enterprises having significant impact on development and designed by the Government to fasten growth and facilitate development; and (3) basic goods and services that are subject to price regulation. ${ }^{24}$

The first thing one may note is perhaps the discretion the regulator - the Trade Practice Commission - enjoys in deciding the [in]applicability of the rules to certain categories of undertakings. Obviously, this risks legal certainty. This is of particular economic implication as the Commission decides [in]applicability of the law to firms only after an alleged violation of the law:

"The broad discretion of the Commission to exempt enterprises from the law, and to do so ex post facto, does not provide the assurances and predictability that would encourage innovation, expansion, or entrance [to a market] by entrepreneurs whose success depends upon free competition.,"25

${ }^{21}$ For details on various limits of European competition law, see e.g., Johns \& Sufrin, at 615 et seq.

22 Art.86 (2), the 1957 Treaty of Rome (the Treaty establishing the European Community). This provision is an instance of legislative approval to the theory that free market principles are not ideal in all situations. For instance, the efficient and uninterrupted provision of some basic public services requires the deliberate granting of exclusive or special rights to certain undertakings involved in the provision of the basic public services. This is obviously against the principle of competitive market. Yet, policy makers in various jurisdictions have long understood the importance of exceptionally doing away with free market principles.

23 For instance, industrial, trade, and other public interest considerations including affirmative actions aiming at rectifying social inequalities have, in some jurisdictions, been given emphasis at the expense of the traditional concerns of competition law, i.e., market efficiency; see, generally, Stewart, Clarke \& Joekes, at 21 et esq. and Adhikari \& Knight-John, at 2-5.

24 Art.5, TPP.

${ }^{25}$ USAID Report, at 59-60. 
Apart from this, there seems to be another greater danger. In the absence of any set of interpretative guidelines to be considered [in deciding applicability or otherwise], the ideal targets of the law may easily be absolved from liability if the Commission discretionarily decides not to apply the law against them. Given the fact that the main actors in the Ethiopian economy (even in sectors that are not exclusively reserved to the state) are big state monopolies who possibly benefit from exemption under Article 5, one cannot help questioning the efficiency or welfare "gains"26 the inapplicability of the law may bring. This would also, at least in the future, be one of the issues that test the impartiality of the administrative organ overseeing the enforcement of the antitrust regulation. ${ }^{27}$

\section{B. Don't We Need Regulatory Rules on Mergers and Vertical Agreements?}

Cartels, intent to monopolise (abuse of dominance), and mergers are the traditional concerns of antitrust regulation. A fairly detailed antitrust legislation includes rules not only on cartels and abuse of dominance but also on mergers - which are of ex ante character. Scholars suggest ex ante or preventive as opposed to curative measure is a better way to fight anticompetitive practices in smaller economies like Ethiopia. ${ }^{28}$ Some studies as well show that ex-ante authorizations such as cartel registrations and competition restraint authorizations are better suited where law enforcement institutions are moderately strong. ${ }^{29}$

However, emerging free market states including Ethiopia still leave mergers unregulated. Though ex-ante authorisation rules are recognised within the context of anticompetitive practices, ${ }^{30}$ explicit merger control regulations are absent in TPP. The absence of merger rules in TPP may perhaps be attributable to the usual developing countries' qualm for it. Many developing countries believe that the creation of domestic monopolies enhances economies of scale and this in return would help international

${ }^{26}$ Assuming that the law's main objective is efficiency and consumer welfare, one may argue any decision of inapplicability is only meant to serve efficiency or welfare purposes - and nothing else.

${ }^{27}$ For now we may safely reckon with what the Commissioner of the Trade Practices Commission has, in a fairly recent scholarly article, stated. According to the Commissioner, a strong case that challenges the impartiality of the Commission is yet to come; see Harqa, at 49.

${ }^{28}$ Adhikari \& Knight-John, at 14 et seq.

${ }^{29}$ See generally Borrel.

${ }^{30}$ See, e.g., Arts.7-9 of TPP which allow various ex-ante rules. 
competitiveness. ${ }^{31}$ Though this might not be miles away from economic truth, especially where export competitiveness is among key developmental objectives, there are competing empirical evidences showing the relevance of merger control regulations for developing countries. ${ }^{32}$ Hence, the absence of rules on merger makes the Ethiopian antitrust regime incomplete ${ }^{33}$ and this situation may inappropriately benefit dominant firms at the expense of consumer welfare and efficiency - which are the declared objectives of the law.

The prohibition of vertical restraints is also unclear from the reading of the statute's provisions dealing with collusive behaviours. ${ }^{34}$ The fact that Article 6(2) enumerates only conventional horizontal ${ }^{35}$ restraints may arguably be taken as a legislative approval of vertical agreements which seldom pose serious competitive problems. However, the unqualified permission of vertical (distribution) agreements may impact on efficiency and, particularly consumer welfare:

“...if practices such as resale price maintenance, excusive and selective distribution are widespread, retailers engaged in significant price discounts will be eliminated from the market, consumers may be deprived of innovative retailing and price discounting so that prices may increase, price competition between suppliers may be softened, [and importantly the situation] may foreclose the market to competitors.",36

\section{Economic Analysis of Comparative Significance of RBPs}

Adjudicatory bodies often apply rules formalistically. This formalistic approach has not been at ease in so far as antitrust enforcement is concerned. There have been attacks on the formalistic judicial approach (in preference for an economic approach) to the analysis of the effects of anticompetitive

${ }^{31}$ Stewart, Clarke \& Joekes at 24; Adhikari \& Knight-John, at 6-7

${ }^{32}$ Stewart, Clarke \& Joekes, at 24.

33 One may, however, argue that merger cases may in some instances be governed by the rules on abuse of dominance. This was the case in Europe before a separate merger regulation has been put in place. But, the rules on abuse of dominance do, as will be seen below, have their own drawbacks that may still leave some merger problems unsolved; thus, further rules on merger control would still be needed.

${ }^{34}$ Harqa, at 47.

${ }^{35}$ Horizontal restraints could simply be equated with collusions between competitors, e.g., two or more suppliers of a product. Whereas, vertical restraints are those collusive behaviours involving non-competitors, e.g., producers and suppliers.

36 Johns \& Sufrin, at 695. It is also unclear whether cartels which falls short of either written or oral agreements are caught under Article 6; see, e.g., Harqa, at 47. 
practices. ${ }^{37}$ Economic approach to the analysis of anticompetitive practices is particularly important not to categorically prohibit alleged anticompetitive practices whose [competitive] advantage, upon economic analysis, would be greater than the disadvantages.

TPP seems to implicitly recognise the importance of economic analysis of anticompetitive practices within the context of ex-ante authorisation rules under Art.7. According to Art.7 of TPP, the Ministry of Trade and Industry, which may authorise agreements between competitors subject to commitments by the later, has to first undertake the necessary studies to ensure that "advantages of the agreement to the Nation is greater than the disadvantages"38 The phrase ensuring that advantages of the agreement to the Nation is greater than the disadvantages seems broad enough to even invite [economic or non-economic] analysis of factors other than the comparative competitive advantages of alleged anticompetitive practices. ${ }^{39}$ This provision seems to introduce an undeclared goal - national economic welfare - of the Ethiopian antitrust regime. Even so, the expressly declared objectives of the law would have dictated only economic analysis aimed particularly at identifying the comparative gains (to, for example, consumers) of supposedly anticompetitive agreements. Understandably, however, arguments based on strategic trade theory call for the relaxation of competition rules to accommodate "the problems of industries that are having serious difficulty competing internationally" even at the expense of consumer welfare. ${ }^{40}$

The rules on Art.7 et seq., however, relate only to ex-ante authorisation. Absent ex-ante authorisation, defences based on comparative competitive advantages of a restrictive agreement seem to be unacceptable by the Commission. Put in other words, there is no clear distinction, under TPP, between object and effect cases ${ }^{41}$ comparable with that recognised in the

\footnotetext{
${ }^{37}$ For a detailed discussion on this point in the European context, see Johns \& Sufrin, at 209 et seq.

${ }^{38}$ Art.7, TPP.

39 It is, for example, argued one of the factors considered under Art.7 is 'national treatment' which may be used to discriminate against foreign companies in favour of domestic ones; see USAID Report, at 60.

${ }^{40}$ See, for example, First H., Structural Antitrust Rules and International Competition: the Case of Distressed Industries, New York University Law Rev. 62 (1987), at 1054; see also Adhikari \& Knight-John, at 11-14, for a fair appreciation of how trade and other areas of public policy impact on the enforcement of competition law.

${ }^{41}$ Some collusive agreements are now known to have as their object the restriction of competition; for example, price fixing, market segmentation, and limitation of output or sales. These obvert cases of RBPs are usually enumerated in legislations as is the case with TPP. Some agreements, on the other hand, do not apparently have the restriction
} 
European competition jurisprudence. Hence, there would presumably be no analysis of economic effects of apparently non-restrictive business practices of undertakings. Consequently, we may risk allowing anticompetitive agreements whose effects are not visible at first sight. Conversely, apparently anticompetitive agreements which upon critical economic analysis might not be prejudicial to either efficiency and/or consumer welfare may inappropriately be punished. ${ }^{42}$

\section{Abuse of Dominance under Article 11 Looks Economically Strange!}

Defining market and assessing the effects of cartels and/or monopoly power in the defined market is now an established part of any antitrust analysis. TPP's rules on abuse of dominance do not seem to be in harmony with this anecdote. They do not explicitly require prior definitions of relevant market and, most interestingly, dominance within it. Despite the express title of Art.11 being abuse of dominance, the provision is addressed to all persons carrying on trade irrespective of their dominance in a certain market. Thus, the prohibition may ironically be applied to firms with insignificant market power in a certain market. $^{43}$ The literal application of this rule does not make any economic sense as regulatory rules on abuse of dominance are basically meant to deal with the conduct of dominant [in a defined market] undertakings. As the author has noted elsewhere, ${ }^{44}$ the Trade Practice Investigation Commission the federal agency that interprets the law - apparently applies the law to all traders irrespective of their status in a defined market. ${ }^{45}$ The current

of competition as their object. As such the identification of latent restrictive effects of such agreements requires further economic analysis - as this is the best known way to look into their economic [competitive] effects on a certain market - before any prohibition.

${ }^{42}$ It seems, however, the Commission considers the actual effects of the anticompetitive practices during the assessment of fine. In fixing the amount of fine, the Commission takes into account, among other things, the seriousness of the offense, the damage caused and the share of the market affected (Art.27, TPP).

${ }^{43}$ See the provisions of Art.11 (1) cited above.

${ }^{44}$ Hailegabriel G., Avoid Misuse of Abuse of Dominance Law, Fortune (14 Dec. 2008).

${ }^{45}$ Even when the Trade Practice Commission interprets the provisions in a manner compatible with the very purpose of rules on abuse of dominance, it has been the interest of the [prosecutor of] Ministry of Trade and Industry that the Commission literally interprets the rules notwithstanding the potentially flawed outcomes of such interpretation. In a certain legal opinion addressed to the Minister, the prosecutor (on Tahsas $23^{\text {rd }} 2000$ E.C.) expressed its disagreement with the (Tahsas $11^{\text {th }} 2000$ E.C) decision of the Commission in the Ministry of Trade and Industry v. Ato Abdulsemed Takele and others and similar other cases -"Teff cases" wherein the Commission 
application of the law would be futile as "prohibiting single-firm conduct without regard to the firm's dominance opens wide the possibility that either competitively neutral or, even, pro-competitive conduct will be prohibited."46

However, a contextual interpretation of Art.11 may dictate the application of the rules on abuse of dominance to only certain undertakings that are dominant in a relevant market. ${ }^{47}$ For one thing, the very stated objectives of the law are efficiency and consumer protection; and the law should not be applied to impede these objectives by, for instance, penalising pro consumer-welfare conducts. For another, the relevant article is headed abuse of dominance, and as such it should be applied to anticompetitive conducts by dominant [in a defined market] undertakings, as it is the case in other jurisdictions, including Europe - the primary material source of Ethiopia's law on competition in general and rules on abuse of dominance in particular.

\section{E. The Trade Practices Investigation Commission}

One of the benchmarks for the effective enforcement of competition law is the establishment of investigative and adjudicatory bodies. ${ }^{48}$ The investigative body (what, in many jurisdictions, is also known as the competition authority) participates in triggering investigations, making recommendations in some policy decisions by the government, and intervening beforehand when undertakings seek ex-ante authorisation of potentially anticompetitive agreements. The adjudicatory body (may be an ordinary court), on the other hand, arbiters on cases involving alleged violations of competition rules.

The separation of the two bodies is commendable. The dangers of fusing the two functions into one agency are, according to Adhikari \& Knight-John, multifaceted:

"If [investigative and adjudicatory powers are not separated], the competition agency may become the investigator, prosecutor, judge...rolled into one. Moreover, if both powers are given to one agency, there could be a tendency in the competition commission to be biased in favour of the investigation report and the judgement could invariably go against the business enterprises, which have been seen as conducting anti-competition practices as per the report of the investigative agency."

dismissed the prosecutor's case as the latter failed to initially establish the market powers of respective defendants.

${ }^{46}$ USAID Report, at 60.

${ }^{47}$ Harqa, at 48.

${ }^{48}$ Adhikari \& Knight-John, at 14.

${ }^{49} \mathrm{Ibid}$, at 15. 
Art.12 of TPP establishes an "Investigation Commission”. They are ppointed by the Prime Minister upon the recommendation of the Minister of Trade and Industry. Members of the Commission are drawn from three organs government, private sector and consumers associations. ${ }^{50}$ Though named the "Investigation Commission", the Ethiopian Trade Practices Investigation Commission is not, an investigatory body. It is rather an adjudicatory body whose power, according to pertinent provisions of the TPP, is to adjudicate ${ }^{51}$ ) of complaints submitted to it by any aggrieved party, subject to the requirement of approval of its recommendations by the relevant authority.

As there is no independent investigatory body comparable with the European Competition Commission or the Office of Fair Trading of the United Kingdom that would act as the police of a competitive market, the Ministry of Trade - to which the Trade Practices Investigation Commission is answerable - has sometimes acted as an investigatory organ. Yet, the prosecutor of the Ministry of Trade and Industry has so far seemed to take care of the investigation of some competition cases related in particular to hoarding - which, under the law, is abuse of dominance - to which the Ministry has been sensitive. Otherwise, aggrieved parties are practically in their own in so far as making their own case is concerned. ${ }^{52}$ This may perhaps be the most serious weakness of the Ethiopian competition regime. To begin with, proving cartels and abuses of dominance are sometimes hard, if not impossible, even to well-equipped competition authorities let alone individual victims who may at times happen to be vulnerable to reprisal from the relatively powerful undertakings. Moreover, victim customers/consumers who more often than not are less organised are unable or unwilling to face the ups and downs of investigating RBPs and subsequently challenging the same. These, in turn, may lead to further entrenchment of anticompetitive practices in the yet fragile market.

50 Art.13, TPP; yet, members have mainly been drawn from the government. It now appears the Commission is functionally non-existent due to internal crisis. Otherwise, it has been composed of five commissioners all of whom are drawn from the ''government',; it has been chaired by an MP, a former Minister of Justice, and has included chief economic advisor to the Prime Minister, governor of the National Bank of Ethiopia, governor of the Quality and Standards Authority of Ethiopia, and commissioner of the Federal Cooperatives Commission.

${ }^{51}$ Stating one of the powers of the Commission, art.15 (1) (a) misleadingly use the term

"investigate". It should rather be read "adjudicate".

52 This has been the case in some competition cases entertained before the Trade Practice Commission. 
Apart from this, the involvement of the Ministry of Trade and Industry in investigation is ironic. The fact that the adjudicatory body - the Trade Practices Investigation Commission - is answerable to the same Ministry coupled with the investigatory function of the prosecutor of the Ministry apparently makes the Ministry the investigator and arbiter of competition cases. Thus, the crucially sought separation of adjudicatory and investigatory functions of competition agencies is seemingly absent in Ethiopia. ${ }^{53}$

The commissioners, assuming primarily other responsibilities, meet regularly once in a month unless extraordinary meeting is called. ${ }^{54}$ The Commission, which does not have its own budget, may be assisted by experts whose employment/ appointment has to be, of course, approved by the Minister of Trade and Industry - to whose ministry the Commission is answerable. ${ }^{55}$ With this limited time and resource, the Commission entertains competition cases along with non-competition ones. This, as rightly noted by some commentators, ${ }^{56}$ may impact on the overall efficiency of the Commission whose success has already been doubted on grounds of independence and competence. ${ }^{57}$

Decisions given by the Commission, upon approval by the Ministry of Trade and Industry, are appealable to the Federal High Court. However, appeal seems to be available only with respect to administrative measures and/or penalty decisions and not against any Commission decisions on points of facts and/or law. ${ }^{58}$ This, coupled with the limitations stated above, may hinder the rendition of impartial judgement.

A new draft trade practices law has been initiated by the Commission with a view, inter alia, to improve the effectiveness of the antitrust regulatory

\footnotetext{
53 The practical fusion of adjudicatory and investigative functions into the organs of the Ministry of Trade and Industry has been a cause for some concern. The temptations of the Ministry to have its cases decided (by the Commission) in its prosecutor's favour is evident in the Ministry's instructions to the Commission in a letter dated 6 Tir 2000 E.C. The letter sought the reconsideration of the Commission's two recommendations dated Hedar $27^{\text {th }} 2000$ E.C. and Tahsas $11^{\text {th }} 2000$ E.C based on the Legal Opinion of Ministry's Prosecutor. These two recommendations involved a total of eight cases.

${ }^{54}$ Art.14, TPP.

${ }^{55}$ Art.15 (1)(f),TPP.

${ }^{56}$ USAID Report, at 63 et seq.; Kibre, at 20 et seq.

${ }^{57}$ Ibid; established in 2004, the Commission has passed a ruling on only one third of the cases brought to it as of Nov.2008 [according to a news report by Fortune, 2 Nov., 2008].

58 See Art.17, TPP.
} 
body. ${ }^{59}$ To the best knowledge of the author, however, the Commission whose investigative and adjudicatory limitations are to be remedied with a purported endorsement of the new draft - is currently out of function. Hence, there are glooms over optimistic developments relating to the structure of the competition agency.

\section{Conclusion}

Antitrust regulations are mainly directed at problems related to monopoly power. They aim at rectifying impediments posed (by monopoly power) on efficiency and consumer welfare through rules that impact on the economic behaviour of business firms. The efficacy of the rules in meeting the desire to prevent deadweight loss, however, depends on many factors such as their scope of application, the relative specificity of the rules, and the room left to economic analysis of alleged violations.

Though it may appear premature to judge the success or otherwise of the new antitrust regime of Ethiopia within only few years of its foundation, some limitations have already been noticed. First, exemptions available to certain undertakings have unnecessarily left the scope of inapplicability of the law wide. Second, additional rules are still needed to squarely address, inter alia, (1) mergers (2) vertical agreements and (3) effect cases. Though efficiency friendly mergers and practices need not be punished, care should be taken not to allow mergers and anticompetitive practices which have restrictive effects on competition. Third, the very objectives of the law would be nuanced by the application of the rules on abuse of dominance to all undertakings without prior market definition and establishment of dominance within it, even though contextual interpretation may partly and tentatively solve the problem. Finally, the legal structure of the Trade Practice Investigation Commission which is an adjudicatory body - and its current institutional crisis coupled with the absence of an independent investigatory body have practically made the antitrust regime handicapped.

Comparative analysis of some of the existing limitation of the regime reveals that the problems may temporarily be tackled by, for example, (1) contextual interpretation of ambiguous provisions and (2) replicating experiences of other jurisdictions, in particular those from where the law has drawn its material sources. For the long run, however, the inadequate Ethiopian antitrust regime needs to be revisited for legislative and structural improvement.

59 “Office to endorse new Trade Practices Law soon”, Walta Information Centre (4, Nov., 2008) [available at www.amharic.waltainfo.com; accessed at 4 Nov.2009]. 